\title{
Collaborative Management for Public Facilities and Biogas on the Village Land
}

\author{
Zaflis Zaim ${ }^{\text {a }}$ \\ ${ }^{a}$ Urban and Regional Planning Department, Islamic University of Riau, Indonesia \\ E-mail Korespondensi: zaflis@eng.uir.ac.id
}

\begin{abstract}
A village land is an asset belonging to the village or common goods, not belonging to individuals, foundations, Institution or companies so that it must be used for the benefit of the village or the administration of government. This research identified the constraints on the use of Bengkok as a village land, exploring the format of collaborative management (co-management) in the utilization of Biogas installation and public facilities such as: composting, chopper, water tank, play group, meeting room and warehouse. The research method was taken with indepth interview and observation to obtain the data through all member of the farmer groups, the religious and community leaders, and village government staff. The results indicated that the utilization and management of the village land by farmer groups were not yet optimal. The cow's milk production was still quite small, volatile, and tended to decline. The decreased milk production resulted in the loss of other processed products such as soap, candy and crackers from milk ingredients. Other impacts included the closing of the business opportunities for fertilizer from livestock manure, and the passive supply of household gas obtained from the biogas installation. This research initiated the need for the role of 5 stakeholders, namely Ungaran Regency government, village government, private parties, social institution, and the local communities in order to collaborate on Biogas and public facilities management. The social institutions were formed to repair or improve the Biogas management and water supply for all facilities on the village land.
\end{abstract}

Key words: Social institution, Bengkok, Common goods, Village land, Co-management.

How to cite (APA 6th Style):

Zaim, Zaflis. (2021). Collaborative Management for Public Facilities and Biogas on the Village Land, 2(1), 1-8. doi: 10.26418/uniplan.v2i1.45886

\section{INTRODUCTION}

The issue of collaborative management (co-management) with various aspects began to emerge around 1985. The essence of co-management is the effort to share power/authority and responsibility between the government and local resource users (Berkes, et al, 1991). Singleton added the definition of collaborative management as 'the term given to the government system by combining state control over local components, decentralizing decision making and accountability, which ideally combines each strength and reduces weakness' (Singleton, 1998). The World Bank interprets the meaning of collaborative management as an effort to share responsibilities, rights and obligations among main stakeholders, particularly local and state communities; in other words, there is a decentralized approach to decision making that involves local resource users in the process' (World Bank, 1999). There are 4 categories of stakeholders according to World Bank that play a role in managing collaboration, namely: the central government, regional government, civil society, and the private sectors.

Other opinions about collaborative management originate from Borrini and team, which is a 'situation where two or more social negotiators establish and guarantee themselves for an equitable distribution of management functions, rights and responsibilities for a given area, area or arrangement natural resources' (Borrini et al, 2000). Other researchers, Carlsson \& Berkes, assess that "the collaboration management or collaborative management is a process of continually solving problems from fixed conditions, involving broad consideration, negotiation, and shared learning in solving network problems" (Carlsson \& Berkes, 2005). This management model can be considered as a science partnership (Berkes, 2009). Even the generation of 
knowledge and learning has become a central issue in management of adaptive collaboration (Olsson et al, 2004; Armitage et al, 2007).

Berkes (2009) outlines eight strategies which are summarized from several references that have been used to facilitate or improve collaboration management, such as bridging knowledge. However, the effort to bridge or deliver knowledge to community requires the presence of an institution that is willing or cares about the achievement of aspects of the community welfare. Social institutions are expected to be able to carry out their functions such as: socialization and dissemination of knowledge, assistance, and proactive efforts in the application of knowledge to the community in a gradual \& sustainable manner. This institution is needed because the bureaucracy in developing countries, which has become the authority to exercise legal control and oversight of environmental issues, has failed to resolve conflicts between resource users (Khator, 2009). Some conflicts actually occur between the community and local government as a resource user (Tjiptabudy and Angga, 2020).

\subsection{Legal Foundation of Village Land}

Indrokilo Sub-village is located in the administrative area of Lerep Village, West Ungaran-Semarang Regency. This village is located at 11021'45"-11023'45" East Longitude, and 0706'30"-07008'50" South Latitude. The area has some customary land in the form of Bengkok ${ }^{1}$ land as many as 46 parcels which are spread almost evenly throughout its territory, including five parcels in the Indrokilo Sub-village. The state recognizes the unity of indigenous and tribal peoples along with their traditional rights. In the Basic Agrarian Law, the customary land rights are converted from the customary ownership rights to the usage rights (Agrarian Law number 5 of 1960).

A Customary Land is land that is under the influence and authority or customary rights of a customary law community and receives a protection or control from the community (Wicaksono and Dwiyana, 2016). The Customary Rights are the highest rights to the land owned by a legal alliance (tribe/village) to ensure the orderly use of land. Therefore, a Bengkok Land can be categorized as a customary land (Tobing, 2009; Rusdianto, 2015). The term Bengkok was well known in the life of Javanese society groups before the Dutch colonial period. According to its use, the Bengkok land is divided into 3 category, namely: the really land, the village cash land, and the Pengarem-arem (Maurer, 1994).

Furthermore, the Law number 6/2014 concerning villages emphasizes that management of village land (Bengkok) must be used for the benefit of the village or the administration of government. Bengkok Land is a customary land managed by the village government, used for development purposes and to improve community services (Tobing, 2009; Village law, number 6 of 2014). However, the designation of the Bengkok Land is still predominantly intended for village officials as a substitute for their wages in carrying out government duties or leading the community (Bzn, 1983; Ramelan, 1999).

\subsection{Chronology of Village Land Utilization by Indrokilo Residents}

Since 1997, the Bayan of Indrokilo Sub-village has entered the retirement age so that the management rights of the Bayan Bengkok Land have been transferred to a handful of residents who want to manage the land using the rental system. The rent is paid by the villagers to the village government through the treasurer. This management right then shifted again to farmer groups in 2007 after going through a village consultation process which was strengthened through the Lerep Village Regulation 03/2007 concerning the Placement of Cattle in the Cage Area. This regulation was responded by farmers by forming a farmer organization called the Ngudi Makmur Farmer Group, where the initial number of members of the organization was 32 people. Other farmer groups were declare in 2008-2009, such as: Mangger Lestari and Tunas Mulia. Mangger lestari have 30 members and focus on derivative products of farm.

At the beginning of the utilization and management of Bayan Bengkok Land, the performance and morale of the farmer/livestock members was quite high (Interview with Jbr, 4 March 2019). This can be seen from the building system of the cattle cows, where the productivity of building facilities continues to

\footnotetext{
${ }_{1}^{1}$ Bengkok (crooked land): A land that is an incentive given to the village head or is also an employee salary in the form of land. During their term of office, they may enjoy the results of land; and after their term of office expires, the land is returned and may not be traded.
} 
increase with the pattern of mutual cooperation, alternately and scheduled. Each farmer group member had the task of helping their partners in the process of building a cage where construction materials, working tools and building materials were provided by each farmer. The spatial distribution of Bengkok land at Indrokilo sub-village can see in the figure 1.

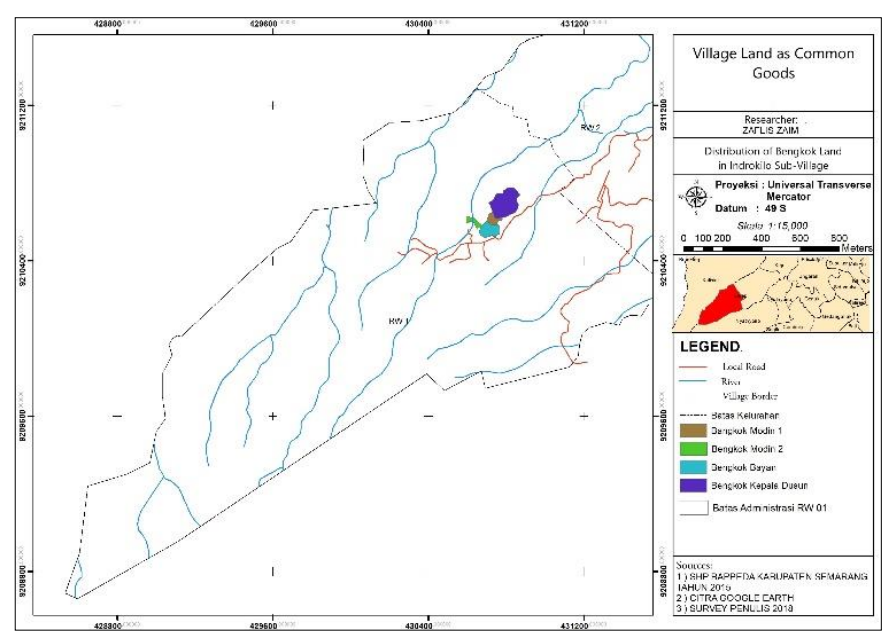

Figure 1. Distribution of Bengkok in Indrokilo, Lerep Village

\section{METHODOLOGY}

This research was focused on the utilization of the Bengkok Land belonging to the village apparatus (Bengkok Bayan or deputy head of sub-village) which was managed by 2 farmer group with Cow livestock activities and their products. The study was conducted by survey with interview techniques especially to 27 breeders. Other respondents were the village officials, religious leaders, and the community such as the head of neighbourhood association. The primary data was collected then tabulated, and explained descriptively.

The field observation was taken to observe important facilities which had been built on the Village Land, the resource user groups such as cattle pens, Biogas, composting, milk warehouses, Chopper, water tank, meeting room and play group. The objects observation was carried out before and after 2007 during the switchover of the Bengkok land management rights from the residents to the group of farmers of Ngudi Makmur and Mangger Lestari.

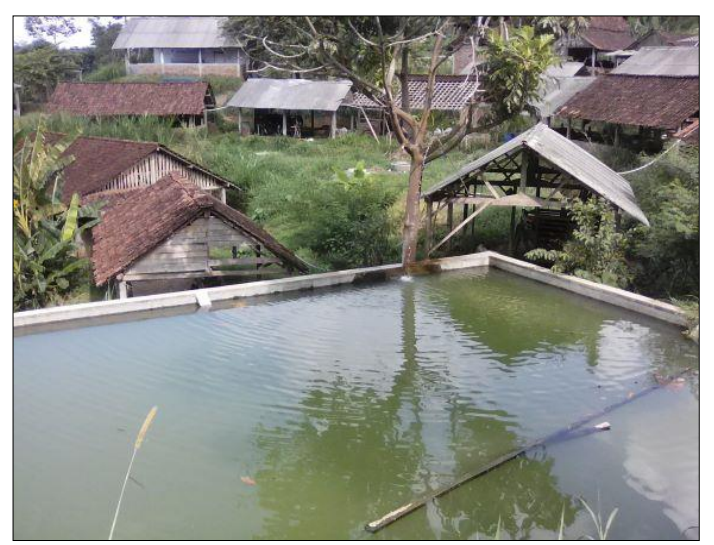

Figure 2. Water tank and Cattle Pens on Bengkok Bayan's land 


\section{RESULT AND DISCUSSION}

The results showed several obstacles and problems that arose during the utilization of Bengkok Land, especially the cattle farming activities. The common problems were: a decrease in the number of farmer group members, from 32 to 22 active members; the reduced ability to finance the livestock farming by farmers, given the dis-balanced expenditure with income; the cow's milk productivity tended to continue to decrease, and the labour cohesiveness of farmer members began to decline. Trend of farmers group can be seen in the table 1 below.

Table 1. Trend of Farmer Groups in Indrokilo

\begin{tabular}{|l|r|r|}
\hline \multirow{2}{*}{ Name of Farmer Group } & \multicolumn{2}{|c|}{ Number of Member } \\
\cline { 2 - 3 } & 2007 & 2019 \\
\hline Ngudi Makmur & 32 & 22 \\
\hline Ngudi Makmur-2 & 0 & 0 \\
\hline $\begin{array}{l}\text { Mangger Lestari } \\
\text { (Woman) }\end{array}$ & 30 & 24 \\
\hline Tunas Mulia (Youth) & 0 & 0 \\
\hline \multicolumn{1}{|c|}{ Total } & $\mathbf{6 2}$ & $\mathbf{4 6}$ \\
\hline
\end{tabular}

Source: Observation \& Interview

The development of milk productivity has continued to decline in recent years. In 2018, there were two to three breeders who got relatively the good milk production from their partners. But in 2019, only one breeder received the very good production. Most of them have decrease in milk production. The development of milk production can be seen in Figure 3.

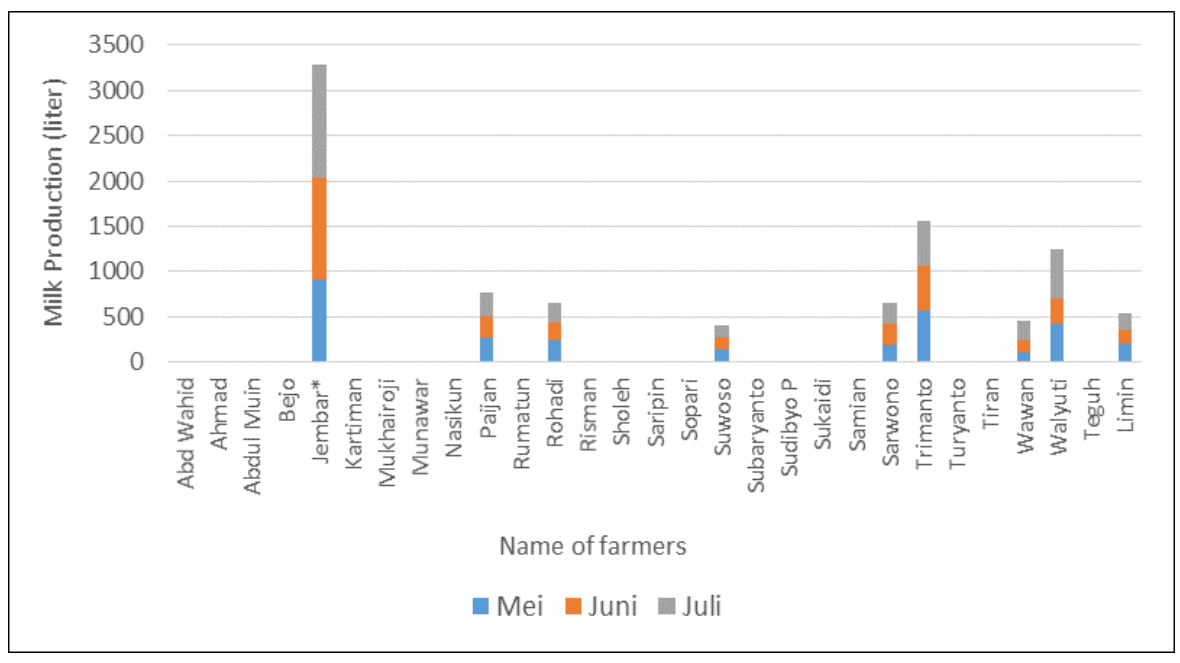

Figure 3. The Number of milk production, May-July 2018

From the general obstacles above, other problems arose such as: the sluggish production of crackers and soap from milk ingredients, and the increased need for manure by farmers for their crops in the fields, which had an impact on the creative development of an organic fertilizer manufacturing business by a group of women farmers (Mangger Lestari group). Another impact was the shrinking volume of cows dung to produce gas from the Biogas well. The table below explains the development of the number of households that received gas supply from the Biogas well and the active members of the farmer group. The receivers of gas supply continue to decline until none of the households currently receive the gas deliveries (Table 2). 
Table 2. Growth of the number of Gas users and

Active members who manage the Village land

\begin{tabular}{|l|r|r|}
\hline \multirow{2}{*}{ Resources Users } & \multicolumn{2}{|c|}{ Households (unit) } \\
\cline { 2 - 3 } & Year 2009 & \multicolumn{2}{|c|}{2020} \\
\hline Receivers of gas supply & 7 & 0 \\
\hline Active members of Ngudi Makmur & 32 & 22 \\
\hline
\end{tabular}

Source: Interview, 2018

The results of the data tabulation show the types of problems faced by the farmers in the management of livestock manure for Biogas material (see table 3). The absence of the biogas installation maintenance costs, the expertise in maintaining the installation, and the people in charge of the installation along with the Biogas well was the most serious problem faced during the procurement of the Biogas well. The depreciation of the number of cattle had impacts on: the Biogas productivity, the struggle for raw materials for manure between the members, and the use of livestock manure for the crops owned by farmers in their fields.

Table 3. Problems faced in managing livestock manure

\begin{tabular}{|l|r|r|r|}
\hline \multirow{2}{*}{\multicolumn{1}{|c|}{ Type of Problems }} & \multicolumn{2}{|c|}{ Opinions } & \multirow{2}{*}{ Total } \\
\cline { 2 - 3 } & Yes & \multicolumn{1}{|c|}{ No } & \\
\hline Biogas installation maintenance costs & 7 & $\mathbf{2 0}$ & 27 \\
\hline Expertise in caring for Biogas installation & 8 & $\mathbf{1 9}$ & 27 \\
\hline Scientific insights in waste management & 15 & 12 & 27 \\
\hline Technical guidance from outside parties & 17 & 10 & 27 \\
\hline Person in charge for daily operation & 9 & $\mathbf{1 8}$ & 27 \\
\hline
\end{tabular}

Source: Interview result, 2019

There is something interesting in the management of cattle dung in this sub-village. Most of the breeders mentioned the existence of technical development efforts from the outside party (Regional Government). However, the current Biogas installation is no longer functioning, the condition of the pipeline is damaged, broken or clogged so that the disposal of livestock manure to the Biogas well is not smooth. This indicates the absence of elements/parties who want to take full responsibility in managing and operating Biogas facilities. Based on the observation, the regional government technical agencies that participated in building Biogas also did not conduct periodic maintenance.

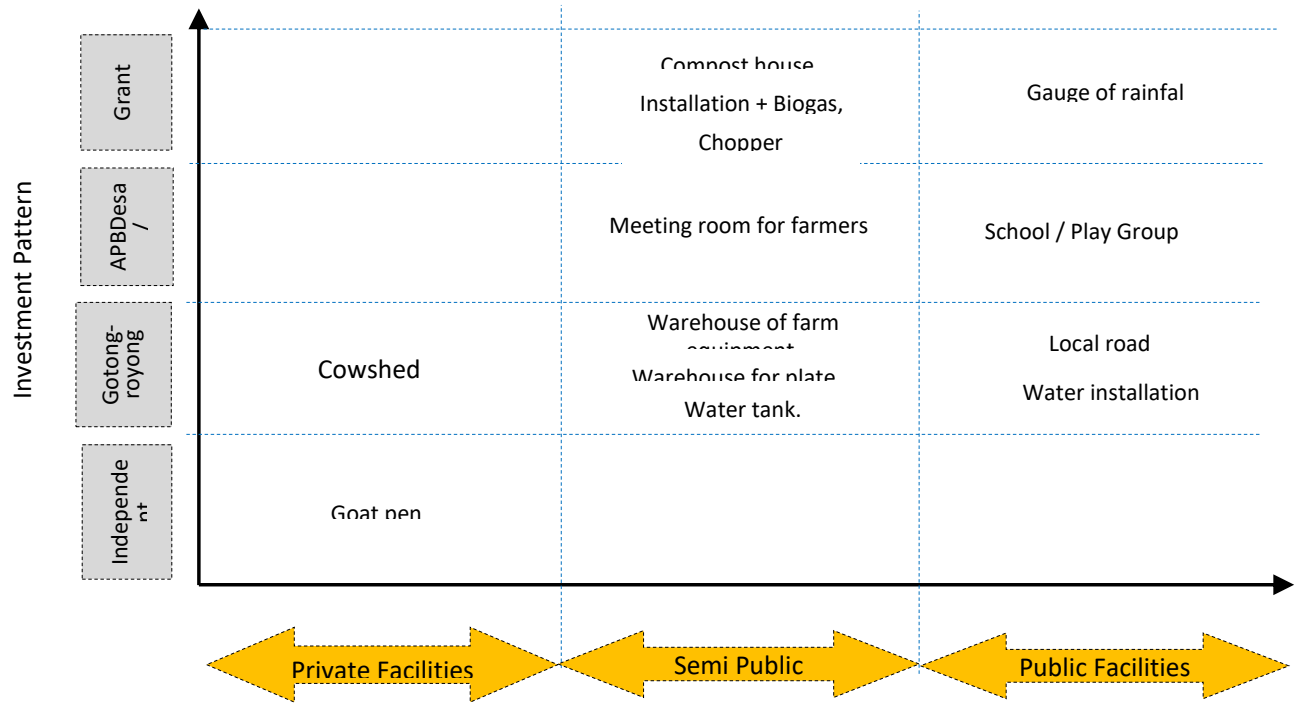

Figure 4. Development investment patterns in the Village Land Based on Function \& Type of Facility 
Figure 4 shows the investment pattern in the construction of existing facilities on Bengkok Land belongings to Lerep Village. The Biogas Installation is a semi-public facility because it can only be used by the members of farmer groups. This installation was built with a grant from a private institution and local government which currently cannot function properly anymore. Another cause is the low ability of financing in the maintenance of Biogas and its network.

From the field conditions, it can be seen that the Biogas facility is not functioning, the absence of elements/parties who are willing to take full responsibility in running the Biogas facility and its treatment, both from elements of the local community, the private sector, or the Regional government. Researcher proposes a collaborative management discourse through the role of social institutions in the utilization of Biogas and public facilities especially in Indrokilo sub-village. The management of social institutions can come from local community components in a region, or come from outside the region.

The working system of social institution is oriented to local community resources. Therefore, they have to be responsible to the community. Everything related to the institution operational comes from the mandatory dues. It's a zakat that collect from each household in Indrokilo sub-village. So, the administrator of social institution will work and endorse effectively the work system chain on the area. The figure 5 below is arranged in relation to the work system chain in managing the collaboration of Biogas and public facilities like play group, meeting room, water tank, chopper and composting room.

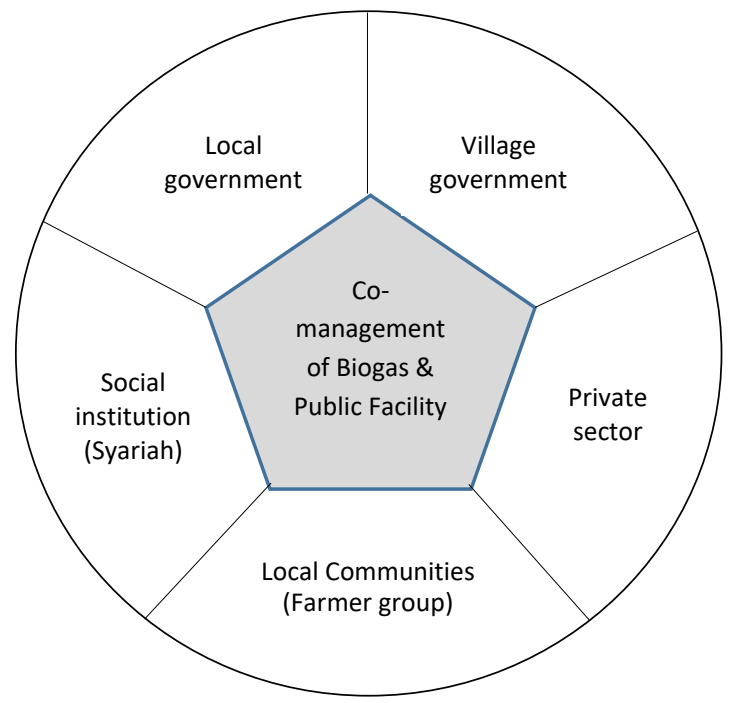

Figure 5. Stakeholder Categories on Public Facility and Biogas Co-management

On the other hand, the capacity of civil society or local communities, especially in rural areas, does not generally describe the written form of obligations, rights and responsibilities of the community in the use of resources, especially the use of shared assets/goods. Due to the absence of written community job descriptions and responsibilities, this has an impact on the resource care aspect. The absence of job descriptions and responsibilities for the use of resources also indicates the absence of the officer or the highest responsibility in the operationalization of a resource.

To formulate the job descriptions and responsibilities for the resource use, the community needs to be accompanied by social institutions. The social institutions must be able to bridge the knowledge, describing the rights or responsibilities, assisting and picking up the community obligations during the process of utilizing the natural resources in their environment. As reviewed by Berkes (2009) that one of the facilitation strategies for a collaborative management is bridging knowledge.

The collaborative management strategies in the use of resources can be pursued through eight ways: bridging knowledge, collaborative production of knowledge, developing collaborative tactics, participatory research, collaborative monitoring, developing participatory scenarios, fair distribution of authority, and downward accountability (Berkes, 2009). In the absence of those responsible for Biogas operations and maintenance, the village government can appoint a social institution to be fully responsible for managing 
Biogas. As a local partner, the social institution monitors the collaborations on priorities that need to be monitored, and helping deciding what needs to be monitored and how (Kofinas, 2002; Mutimukuru et al, 2006).

Another strategy is the downward accountability process, where agents are organized to be able to carry out the vertical accountability mechanism, such as being responsible to the ministry (Be'ne' and Neiland, 2004). Agencies such as social institutions can report vertically Biogas management, and monitoring all activities for the facilities.

\section{CONCLUSION}

In carrying out its functions, this social institution together with local religious leaders can invite the community to participate in collecting funds through the zakat, donation or alms. The funds are used to finance the operations of the Institute. Concretely, social institutions can take the form of nongovernmental organizations (NGOs) and not profit or profit-making institutions. This social institution solely plays a role in efforts to improve the welfare of the community, in this case the use of Biogas wells for energy needs in the household.

The spirit of participation can be developed given the common interests. Communities choose to participate if they see the benefits of a proposed facility, or if they have an economic interest especially in the outcome of a decision (Sanoff, 2000). As a complement, it requires constant physical presence as a tactic to build cooperation and cover up institutional weaknesses (Wollenberg et al, 2007; CIFOR, 2008).

\section{ACKNOWLEDGEMENTS}

We say thanks LPDP (Educational Fund Management Agency) for the research cost assistance, the Rector of Islamic University of Riau, and Semarang Regency Government for the data and permission. We also would like to thanks very much the farmers group, research assistant and local actors for their help or contribution.

\section{REFERENCES}

Armitage, D., Berkes, F., Doubleday, N. (2007), “Adaptive Co-Management: Collaboration, Learning, and Multi-level Governance". University of British Columbia Press, Vancouver

Borrini-Feyerabend, G., Farvar, M.T., Nguinguiri, J.C., Ndangang, V. (2000) "Co-management of Natural Resources: Organizing Negotiation and Learning by Doing", Kasparek., Heidelberg Germany (http://nrm.massey.ac.nz/changelinks/cmnr.html.)

Berkes, F., George, P., Preston, R., (1991) "Co-management: the evolution of the theory and practice of joint administration of living resources", Alternatives 18 (2), 12-18

Berkes, F (2009) "Evolution of co-management: Role of knowledge generation, bridging organizations and social learning", Journal of Environmental Management 90, 1692-1702

Bzn, B. Ter Haar (1983)."Asas-Asas dan Susunan Hukum Adat", Pradnya Paramita, Jakarta, Indonesia

Be'ne', C., Neiland, A.E. (2004) “Empowerment reform, yes. But empowerment of whom? Fisheries decentralization reforms in developing countries: a critical assessment with specific reference to poverty reduction". Aquatic Resources, Culture and Development 1, 35-49

Carlssona., Lars, Berkes. Fikret (2005) "Co-management: concepts and methodological implications", Journal of Environmental Management 75, 65-76

CIFOR (2008) “Adaptive Collaborative Management Can Help us Cope with Climate Change”, Info brief No. 13. Center for International Forestry Research. 4 pp

Khator, Renu., (2009) "Bureaucracy and the Environmental Crisis: A Comparative Perspective in Bureaucracy and Administration", Farazman, Ali (Edt). Taylor and Francis Group, New York

Kofinas, G., (2002) "Community contributions to ecological monitoring: knowledge co-production in the U.S", Canada Arctic Borderlands. In: Krupnik, I., Jolly, D (Eds.), The Earth is Faster Now. Arctic Research Consortium of the United 
States, pp. 54-91. Fairbanks

Maurer, Jean-Luc. (1994) “Pamong Desa or Raja Desa dalam Leadership in Java: Gentle Hints, Authoritarian Rule” (by Antlöv, H. \& Cederroth. S) Routledge \& Curzon, pp 105-106

Mutimukuru, T., Kozanyi, W., Nyrenda, R. (2006) "Catalyzing collaborative monitoring process in joint forest management situations: the Mafungautsi forest case, Zimbabwe". Society and Natural Resources 19, 209-224

Olsson, P., Folke, C., Hahn, T., (2004). "Social-ecological transformation for ecosystem management: the development of adaptive co-management of a wetland landscape in southern Sweden", Ecology and Society 9 (4), 2

Available from: http://www.ecologyandsociety.org/vol9/iss4/art2/.

Rusdianto, Akhmad Zakky (2015) “Analisis Yuridis terhadap Pengelolaan Tanah Bengkok Di Desa Sepanyul, Kecamatan Gudo Kabupaten Jombang", Skripsi, Fakultas Hukum Universitas Negeri Semarang

Ramelan, Eman (1999) Keberadaan Tanah Bengkok atau Ganjaran Dalam Perspektif Hukum di Indonesia, Jurnal Yuridika, Vol 14.

Singleton, S., (1998) Constructing Cooperation: The Evolution of Institutions of Co-management, University of Michigan Press, Ann Arbor

Sanoff, Henry (2000) "Community Participation Methods in Design and Planning", John Wiley and Sons Incorporate Canada.

The World Bank, (1999) "Report from the International Workshop on Community-Based natural Resource Management (CBNRM)", Washington, DC, 10-14 May 1998. URL:http://www.worldbank.org/wbi/conatrem/

Tjiptabudy, Jantje and La Ode Angga (2020) "Customary Rights Regulations in the Eti Village of West Seram Regency Maluku Province", International Journal of Scientific \& Technology Research, Vol. 9 (01)

Tobing, Ary Anggraito (2009) “Eksistensi Tanah Bengkok Setelah Berubahnya Pemerintahan Desa Menjadi Kelurahan Di Kota Salatiga", Tesis, Program Pasca Sarjana Universitas Diponegoro Semarang.

Undang-Undang Pokok Agraria (Agrarian Law number: 5 / 1960).

Undang-Undang Desa (Village Law number: 6/2014)

Wicaksono, Anggit \& Dwiyana, Achmad (2016) "Pengelolaan Tanah Bengkok sebagai Hak Asal Usul Setelah Berlakunya Undang-Undang Nomor 6/2014 tentang Desa: Studi Kasus Di Kabupaten Kudus", Jurnal Program Studi IImu Hukum Fakultas Hukum, Universitas Muria Kudus.

Wollenberg, E., Iwan, R., Limberg, G., Moeliono, M., Rhee, S., Sudana, M. (2007) "Facilitating cooperation during times of chaos: Spontaneous orders and muddling through in Malinau District, Indonesia", Ecology and Society 12 (1), 3. 